\title{
Learning Needs Analysis: Thematic Teaching Book Based on HOTS Assisted with 3D Stereoscopic Images to Improve Critical Thinking Ability of Elementary School Students
}

\author{
Dede Permana $^{1} \&$ Utomo $^{1}$ \\ ${ }^{1}$ Elementary Educational Programs, Faculty of Business dan Humanities, Nusa Putra University, Sukabumi, Indonesia \\ dede.permana@nusaputra.ac.id; utomo@nusaputra.ac.id \\ *Corresponding Author: dede.permana@nusaputra.ac.id
}

\begin{abstract}
This study is descriptive explorative which aims to see the needs of teachers and students in implementing High Order Thinking Skills (HOTS) based learning in thematic learning. The research objectives were achieved through observation, interviews and document study. The results of observations show that in learning students have problems with learning interest, this can be seen when students do activities that are not related to learning. Meanwhile, the results of the interviews which were supported by document study data revealed that in the thematic book the conceptual presentation was not given in depth. It is necessary to add various activities that support the student learning process. In addition, the teacher argues that it is necessary to provide pictures as an illustration of the teaching concept given, this is because elementary school students are in the 7-11 year age range who are still in the concrete operational thinking stage which requires textbooks that can present abstract concepts. concretely. Based on this, it is natural that students are not interested in participating in learning. This study concludes that the thematic textbooks currently used have shortcomings in the presentation of HOTS material and supporting activities. To cover these shortcomings, it is necessary to develop thematic books that have a more complete concept of material and are made according to the characteristics of elementary school students and contain various activities to support HOTS ability improvement. The development of textbooks is needed as an effort to increase learning interest so that learning objectives can be maximally achieved.
\end{abstract}

Keywords: HOTS; 3D stereoscopic; thematic learning; critical thinking; elementary schools

\section{Introduction}

Learning in schools must always be able to encourage students to be better at receiving knowledge through observation, questioning, reasoning, and presenting the knowledge they have acquired in carrying out learning. Students are expected to be more creative, innovative, and productive in order to be able to solve problems in learning activities. According to Ibrahim (2016) in the 2013 curriculum scheme, learning is carried out to shape character, build knowledge, attitudes, and habits to improve the quality of student life. Learning activities are expected to be able to empower all potential students to master the expected competencies. Students are able to develop attitudes and experiences according to their potential so that the role of the teacher is no longer as a provider of knowledge, but as a facilitator or helping students so that students are able to master the various competencies expected by the curriculum.

Implementation of the 2013 curriculum in a thematic framework in elementary schools requires a comprehensive understanding of the teacher's concept, preparation, and availability of learning support facilities. Teachers have a major role in implementing the curriculum because the success of the curriculum depends on the activities and creativity of teachers in developing and implementing it. In addition, in implementing the learning process, the characteristics of students who are the objects of learning must be considered. Primary school students are in the age range of 7-11 years, according to Piaget (Danim and Khairil, 2011: 78), which reveals that the intellectual development of children at elementary school age (7-11 years) is still unable to think logically or abstractly. Children's way of thinking is limited to concrete, real, definite, and uni-directional things, a term that shows more real and concrete experiences than abstractions. Therefore, a learning atmosphere is needed that is in accordance with the thinking stage of students. If learning is not in accordance with the students' thinking stage, learning will be meaningless. 


\section{Literature Review}

\subsection{High order Thinking Skills (HOTs)}

HOTS Higher Order Thinking Skills can be defined as "higher order thinking skills/abilities". Learning in the curriculum given to children should be able to motivate students to think critically, logically, and systematically according to their characteristics, and have higher order thinking skills or HOTS.

Anderson categorized the level of thinking as follows: (1) Remember: Presents facts from memory about facts; (2) Understanding: Interpreting the material being studied in one's own words/sentences; (3) Apply: Carrying out executing, using implementing procedures for new situations; (4) Analyze, Grouping information/phenomena into important parts; (5) Evaluate: Determine whether the conclusion is in accordance with the description/facts; (6) Create: Develop a hypothesis, plan research, develop new products.

Higher Order Thinking Skills is defined as including critical, logical, reflective, metacognitive and creative thinking (King, 2011). All of these skills are active when a person is faced with unusual problems, uncertainties, questions and choices. The successful application of these skills lies in validating explanations, decisions, performances, and products in the context of existing knowledge and experience and the continued development of these or other intellectual skills. Higher Order Thinking Skills (HOTS) are highlevel cognitive abilities (thinking) which in the taxonomy of cognitive education objectives consist of the ability to analyze, evaluate, and create. Each HOTS level has different abilities as listed in the table 1.

Table 1. HOTs Level Ability

\begin{tabular}{lll}
\hline HOTS level & \multicolumn{1}{c}{ Ability } & \multicolumn{1}{c}{ Verb } \\
\hline Analysis & $\begin{array}{l}\text { Classifying important sources of information / objects } \\
\text { observed/social, natural, cultural phenomena }\end{array}$ & $\begin{array}{l}\text { differentiation of information groups selecting } \\
\text { information based on groups determines the } \\
\text { important focus of an information }\end{array}$ \\
\cline { 2 - 3 } & & $\begin{array}{l}\text { organizing linkages between groups / } \\
\text { arranging to find coherence between groups } \\
\text { to create a (new) structure for group } \\
\text { information }\end{array}$ \\
& Determine the linkages between components & $\begin{array}{l}\text { give a label to the group that was developed } \\
\text { to find the author /information provider }\end{array}$ \\
\cline { 2 - 3 } & $\begin{array}{l}\text { ind the main thoughts /values of the author or } \\
\text { information provider }\end{array}$ &
\end{tabular}

Determine the suitability of the problem, description Continuity checking detects the same and conclusion / proportion of a form / proportion of a elements monitoring the testing activities presentation of an activity.

Determine the suitability of the method / procedure / technique / formula / principle with the problem

criticize the strengths and weaknesses of the information or its parts provide an assessment based on criteria

\begin{tabular}{lll}
\hline Create & Developing a hypothesis & develop problem-solving procedures \\
\cline { 2 - 3 } & Planning research / projects / activities / creation & plan designing \\
\cline { 2 - 3 } & developing new products & Produce and reconstructs \\
\hline
\end{tabular}

Higher order thinking occurs when a person takes new information and information stored in memory and interconnects and/or rearranges and expands this information to achieve a goal or find possible answers in a confusing situation. Various goals can be achieved through higher order thinking. Decide what to believe; decide what to do; creating new ideas, new objects, or artistic expressions; making predictions, and solving irregular problems.

\subsection{D Stereoscopic Images}

Banks, et al (2012) stereoscopic images are images that use three-dimensional (3D) imaging that works by creating the illusion of depth in a particular image. Stereoscopic images will provide spatial information that will trick the user's brain into seeing the depth of an image. Braynt and Bay (2011: 93) Images with stereoscopic effects are images achieved by sending two images to the viewer, one for each eye, which depicts the same scene from a slightly offset point of view. If two images are the same, the brain coalesces into a single image with the illusion of depth. 


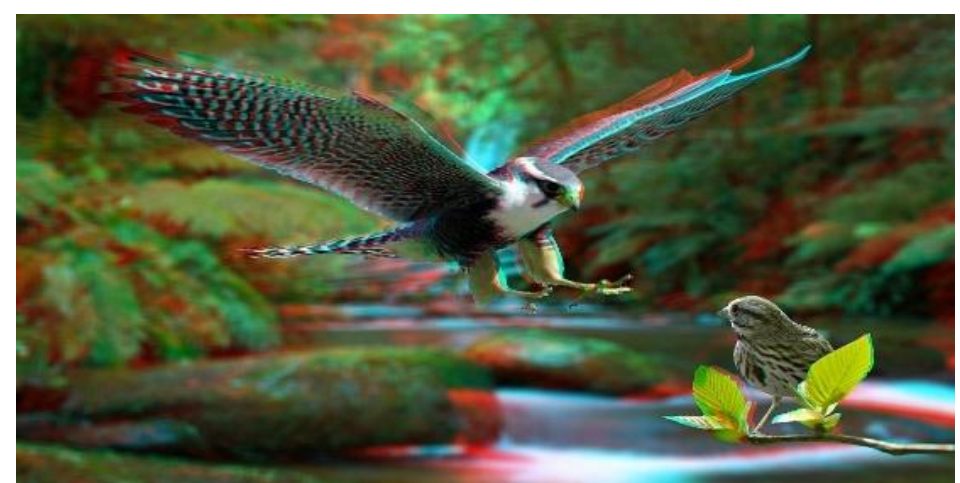

Figure 2. 3D Stereoscopic Images

In line with the above statement, Onural (2011: 7) states that stereoscopic images are images based on capturing two different 2D images that are similar to the natural images obtained by two eyes at slightly different distances (disparity), followed by simultaneous transmission of each. the image with the appropriate eye. Peres (2007: 729) stereoscopic images are images that involve two (or more) still images that are made from slightly different positions, each of which is then presented to the right eye of the viewer. To view images with the 3D Stereoscopic concept, you must use a special tool, namely 3D glasses with red-cyan or red-green lenses. Jahne (2002: 210) uses glasses with a red filter on the right eye and a green or blue filter for the left eye. In this way, the right eye only observes the green eye and the left eye only the red image. This stereoscopic method is called the anaglyph method. This method does not require any special hardware and can be projected, displayed on any RGB monitor, or printed with a standard printer. In line with the previous opinion, Carrier (2012: 53) images with stereoscopic views involve controlling the existing image, presented to the eye so that it can provide two different visual images to the brain simultaneously. Monnes (2013: 12) Stereoscopic view works by displaying two different images with the left and right eyes, simulating what we see in real life, then the brain combines the two images to create 3D depth perception. Englund (2010: 7) states that the working principle of stereoscopy is to make each eye see its own landscape image, as in the real world. When looking in the real world, the eye sees two slightly different images, the image for each eye is different, but the brain can sense the depth of the image. In line with some of the opinions above, Mehrabi (2013: 92) states that the working principle of stereoscopic 3D images is dependent on binocular vision. Binocular vision is vision that occurs when the two eyes are used together.

\section{Materials and Methods}

In this study, we tried to go into the field to see the implementation of the 2013 curriculum, see what if there were still obstacles in learning so that finally we could find out what they needed to overcome these obstacles. This study focuses on the implementation of thematic learning in grade IV elementary schools. The purpose of this study was to determine which textbooks need to be developed in developing students' higher order thinking processes within the thematic learning framework. The research results are expected to provide information about the needs of teachers and students in learning, so that from the results of this study, efforts can be made to meet the needs of teachers and students in learning. This research is a needs analysis study consisting of field studies and literature studies. This type of research is a descriptive exploratory research which was conducted in August-September 2020 in several elementary schools in Sukabumi. The subjects of this study were teachers and fourth grade elementary school students. The techniques used in this research are observation, interview and document study. Observations were made to see the conditions of learning being carried out, interviews were conducted to find out firsthand the opinions of teachers and students regarding the learning process being carried out, while document studies were carried out to examine the textbooks being used.

\section{Results and Discussions}

\subsection{Literature Study}

Research that aims to develop high order thinking skills-based learning has been successfully carried out by several previous researchers, Shidiq, et al. (2015) concluded that all students can think, but most students need encouragement and guidance for higher order thinking processes. Fanani (2018: 57) states that through HOTS-based learning, it will be able to increase student motivation and increase learning achievement; Furthermore, Sara, et al (2020: 52) revealed that the low HOTS of students started from a lack of understanding of the material being taught and its use in everyday life, less thorough in the process of solving questions. Meanwhile, research that aims to develop learning through 3D Stereoscopic media has 
previously been carried out by several researchers, including: Joseph (2011) entitled Stereoscopic Visualization as a Tool For Learning Astronomy Concepts, Trindade, et al (2012) entitled Science learning in virtual environments, Ferdig R, et al (2015) entitled Using Stereoscopy To Teach Complex Biological Concepts, Price, et al (2015) entitled Position Paper on Use of Stereoscopic to Support Science Learning, and Cristiadi (2014) entitled The use of stereoscopic 3D media in Civics learning for improve the character of students.

Joseph (2011) in his research concluded that three-dimensional (3D) visualization is very useful. 3D Visualization education tools tend to be most useful when demonstrating concepts that involve very large such as astronomy, or very small ones such as nanotechnology. Stereo visualization allows students to get used to and see from a world that is difficult or impossible to experience in real life. The research conducted by Joseph (2011) has similarities and differences with the research to be carried out, the similarities lie in the variable use of stereoscopic 3D visualization. While the difference lies in the type of research, the research subject. Trindade, Fiolhais and Almeida (2002), explain that, since science is taught in three dimensions (3D), visualizing and manipulating shapes is very helpful in their learning. Learning is also considered effective and provides visual stimulation for them. The conclusions from the research of Trindade, Fiolhais and Almeida show that 3D virtual environments can help students with high spatial aptitude to gain better conceptual understanding. Ferdig R, Blank J, Kratcoski A, and Clements R (2015) in their research, use stereoscopic 3D images to teach complex scientific concepts. Three-dimensional stereoscopic (3D) can effectively be used to engage students with complex disciplinary content because it is presented with informative representations of abstract concepts. In addition, this shows that it shows that stereoscopic 3D can improve learning and retention in some educational materials, especially science concepts. Science phenomena in 3D as they are in real life allow users to relate these spatial relationships and easily understand the concepts making the main connections between structure and function. Students who used Stereoscopic 3D had significantly higher test scores than those who did not. In addition, students enjoy 3D objects, and it is among their top choices for learning about complex concepts.

Price, et al (2015) stated that stereoscopic media has the potential to benefit learning. Stereoscopic use is used to make something unique. This medium can accommodate special requirements for understanding topics and tasks with the visualization of complex objects and phenomena where the depth of the image is close to convey the core ideas. Cristiadi (2014) revealed that the design of stereoscopic 3D-based learning media is in demand by teachers as a new learning medium that supports learning in schools. This is because the message in the material will be conveyed well. By making the media using stereoscopic 3D, it makes children enthusiastic and interested in the presence of 3D glasses that are designed according to the characters in the learning media. From the three studies above, it can be concluded that stereoscopic 3D images make it easy for teachers to visualize abstract aspects of science, so that students can understand scientific phenomena in a concrete way. This is because not all science objects can be brought into the classroom and can be visited outside the classroom. In addition, the presence of stereoscopic 3D image media makes children enthusiastic and interested in learning.

\subsection{Field Study}

Observation

Observations are made when learning is taking place, we observe the things students do when they carry out learning. The observation sheet for the analysis of the need for textbook development contains the following questions:

1. How do students react to the thematic learning process in class based on observations during learning ?.

2. What are the obstacles in thematic learning ?.

3. How are the learning methods and learning strategies applied to thematic learning in elementary schools?.

4. What are the learning materials used in thematic learning in elementary schools?.

5. What is the opinion of the teachers/teachers if thematic learning is developed HOTS-based textbooks with the help of Stereoscopic 3D Images?.

6. What is the opinion of the teachers if the development of HOTS-based textbooks with the help of stereoscopic 3D images will improve the high-level thinking processes of elementary school students ?.

Based on observations during learning, students' reactions to the learning process were still less enthusiastic. Learning is carried out through lectures, discussions and questions and answers. However, things that are of concern when learning takes place include students tend to be passive in participating in the learning process, the textbooks used are not read by students, even students do activities that are not related to learning at that time. In addition, students are not motivated to answer teacher questions. In detail, the results of the observations are as follows. 
Table 2. Results of Observations

\begin{tabular}{|c|c|c|}
\hline No. & Indicator Observations & Analysis Results \\
\hline 1 & $\begin{array}{l}\text { Student reactions to the } \\
\text { thematic learning process in } \\
\text { class are based on observations } \\
\text { during learning }\end{array}$ & $\begin{array}{l}\text { Only some students are active because of the lack of basic concepts } \\
\text { obtained. } \\
\text { Students' enthusiasm in learning is still lacking, because the material } \\
\text { development is still simple. } \\
\text { Students are less motivated in carrying out learning activities }\end{array}$ \\
\hline 2 & $\begin{array}{l}\text { Factors that become obstacles in } \\
\text { thematic learning }\end{array}$ & $\begin{array}{l}\text { The availability of concepts in teaching materials is limited, so } \\
\text { additional supporting textbooks are needed to support thematic } \\
\text { learning } \\
\text { Teaching materials need to be developed in an attractive manner and in } \\
\text { accordance with the character of the fourth grade students. } \\
\text { Students still have difficulty understanding the concept of learning } \\
\text { because of limited examples / illustrations. }\end{array}$ \\
\hline 3 & $\begin{array}{l}\text { learning methods and learning } \\
\text { strategies applied to thematic } \\
\text { learning to increase HOTS }\end{array}$ & $\begin{array}{l}\text { Discussion } \\
\text { Questions and answers } \\
\text { Lecture } \\
\text { presentation }\end{array}$ \\
\hline 4 & $\begin{array}{l}\text { learning materials used in } \\
\text { thematic learning in elementary } \\
\text { schools }\end{array}$ & $\begin{array}{l}\text { Integrated Thematic Textbook published by the Ministry of Education } \\
\text { and Culture. } \\
\text { Student Worksheets. }\end{array}$ \\
\hline
\end{tabular}

\section{Interview}

The results of interviews with teachers showed that teachers and students in carrying out learning needed additional textbooks. This need is because the integrated thematic book provided by the government contains material that is not in-depth. So that the learning provided cannot answer the learning objectives completely. In addition, students need textbooks that are made based on the developmental stage of their thinking.

Table 2. Development Stages of Thinking

\begin{tabular}{|c|c|c|}
\hline No & Interview Indicators & Analysis Results \\
\hline 1 & $\begin{array}{l}\text { Opinions and suggestions of the teachers if } \\
\text { thematic learning develops HOTS-based } \\
\text { textbooks with the help of Stereoscopic 3D } \\
\text { Images }\end{array}$ & $\begin{array}{l}\text { 1. Urgently need additional textbooks so that thematic learning is more } \\
\text { conceptual and interesting. } \\
\text { 2. will greatly assist the development of students' thinking processes } \\
\text { according to student characteristics. } \\
\text { 3. Books need to be enriched with additional material so that the concepts } \\
\text { given to students become more varied. } \\
\text { 4. Textbooks containing various HOTS-based learning activities need to be } \\
\text { developed to improve students' critical thinking processes. } \\
\text { It needs to be accompanied by attractive pictures and provide examples of } \\
\text { the concepts being taught. }\end{array}$ \\
\hline 2 & $\begin{array}{l}\text { The opinions and suggestions of the } \\
\text { teachers if the development of HOTS- } \\
\text { based textbooks with the help of } \\
\text { stereoscopic 3D images will improve the } \\
\text { high-level thinking processes of } \\
\text { elementary school students }\end{array}$ & $\begin{array}{l}\text { 1. HOTS-based thematic textbooks assisted with stereoscopic 3D images are } \\
\text { deemed necessary because they will be able to increase the variety of } \\
\text { teaching materials, increase students' insight, understanding, and interest } \\
\text { in learning. } \\
\text { 2. Books must be accompanied by various activities that support the high- } \\
\text { level thinking process of HOTS students. } \\
\text { 3. Images with an attractive presentation are given to suit the thinking level } \\
\text { of elementary school students. }\end{array}$ \\
\hline
\end{tabular}

\subsection{Document Study}

\section{Analysis of Curriculum}

Analysis of curriculum documents is focused on the analysis of the basic competencies listed in the content standards. Curriculum analysis will provide an overview of the form of textbook development. The results of the analysis are used as indicators of learning achievement. The description of basic competency and indicators of competency achievement is a consideration to determine the concepts required in the learning process.

\section{Analysis of Teaching Documents}

Based on the results of document analysis in the form of the syllabus, lesson plans, and textbooks used, it can be seen that the syllabus used is an integrated thematic syllabus and lesson plans. The textbooks used are still textbooks that are distributed by the government nationally. After analyzing the textbook, it has been compiled based on the syllabus that has been formulated. Judging from the way the material is presented, the material presented in the teaching material is in accordance with the curriculum used in 
schools. The language and readability of the material are also in accordance with the level of understanding of the students. However, there are some materials in the textbook that are incomplete, one example can be seen on page 20 of textbook, on that page it is described as follows:

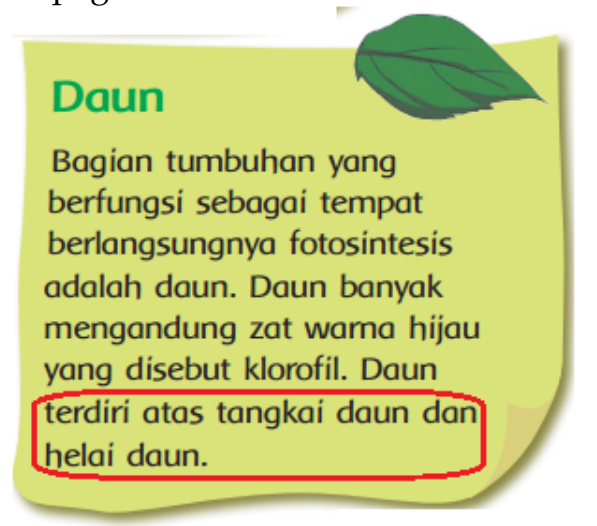

One example of incomplete material exposure

The existence of incomplete material means that learning carried out in schools currently revolves around learning containing Low Order Thinking Skills (LOTS). Learning is still charged with remembering or memorizing and simple understanding. In today's society life demands more than that. Individuals must be able to survive in society and the problems are increasingly complex so that learning is needed that leads students to be able to survive in life in society. LOTS-filled learning has to change and leads to HOTS-loaded learning.

Teaching materials have an important position in learning and have an effective influence in increasing the activities and learning outcomes of students. Octaviani's 2017 research suggests "the quality of the ability of elementary school students' resources, one of which is very dependent on teaching materials so that it has an impact on the quality of learning". Referring to this opinion means determining the quality of students and teaching materials that can direct learning. The implementation of learning that is carried out sometimes adjusts the teaching materials used or the teacher chooses teaching materials that are in accordance with what he wants so that learning is more effective and makes it easier to achieve the desired learning goals. The development of teaching materials containing HOTS needs to be developed due to the times, needs and demands of today's society which are very complex. The development of teaching materials has the aim of providing teaching materials that are in accordance with the demands of the curriculum by taking into account the needs of students, namely teaching materials that are in accordance with the characteristics and settings or the social environment of students. Helping students in obtaining alternative teaching materials in addition to textbooks that are sometimes difficult to obtain, and making it easier for teachers to carry out learning (Kemdikbud, 2018:5). Higher order thinking skills need to be instilled and developed from an early age. Learning in elementary schools must contain higher order thinking skills even though it is only a simple activity. Development of teaching materials containing HOTS needs to be developed for students in elementary schools. One that was developed was HOTS-loaded teaching materials in learning the theme of unity in difference in grade VI primary schools. The theme of unity in difference was chosen because in this theme higher order thinking skills were needed. Unity in differences is not just a theory or knowledge that the teacher conveys to students and then disappears after the lesson is over. Zamroni (2011) suggests "there is a need for efforts in the school environment to instill awareness of life in a multicultural society and develop an attitude of tolerance and tolerance in order to realize needs and the ability to cooperate with all existing differences." HOTS-filled learning is one way because learning about unity in difference is not just a doctrine but learning that can actually make students gain understanding and knowledge about unity in differences in Indonesia through their own discoveries and experiences.

In addition, starting from the fact in the field that it is necessary to have an illustration in a teaching material it is very necessary to pay attention to it. Illustration will be a support in explaining a material concept. Giving examples and analogies can increase students' understanding and interest in learning a material.

\section{Conclusions}

Based on the research data, it can be concluded that in the thematic learning process teachers and students need additional teaching materials that can help improve high order thinking skills and deliver more complete concepts. Teaching materials that need to be developed are thematic textbooks that are able to help improve HOTS abilities through activities and evaluations that generate HOTS. Thematic textbooks are 
developed as additional textbooks to support thematic learning in grade IV. Textbooks are chosen because through textbooks they can be easily accessed by teachers and students, besides that the teacher has broader guidelines regarding the material to be provided. and students will have the convenience of understanding the material in depth. In addition, textbooks also need to be developed based on the characteristics of elementary school students in order to attract students' interest in learning. This study is used as a preliminary study (preliminary) to carry out research and development of suitable textbooks to answer the needs of teachers and elementary school students in implementing thematic learning that seeks to improve high order thinking skills.

\section{Acknowledgement}

The authors would like to thanks the to study colleagues and parties related to this study for their assistance in the completed this paper.

\section{Author's Contributions}

All authors discussed the results and contributed to from the start to final manuscript.

\section{Conflict of Interest}

The authors declare that they have no competing interests.

\section{References}

Banks, M, Read, J, Allison, R, Watt, S. (2012) Stereoscopy and the human visual system. SMPTE motion imaging journal. 121(4), 24-43. doi: 10.5594/j18173.

Bryant, John., \& Bay, Jason. (2011). Stereoscopic Technologies and Effects.Washington: IEEE Computer Society Publisher

Carrier, Mark. Dkk. (2014). Pathways for Learning from 3D Technology. International Journal of Environmental and Science Education. V(3) hlm. 53-69. https://eric.ed.gov/?id=EJ972444

Christiadi, Gladisa, T. (2014). Perancangan Media Pembelajaran Penanaman Nilai Moral Peduli Lingkungan Alam Anak Usia Dini dengan Menggunakan Animasi 3D Stereoscopic. (Disertasi). Fakultas Teknologi Informasi, Universitas Kristen Satya Wacana. Salatiga.

Danim, and Khairil (2011), Porfesi Kependidikan. Bandung: Alfabeta.

Englund. Rickard. (2010). Rendering Methods for 3D Fractals. (Unpublished master's thesis). Retrieved from http:/ /diva-portal.org/smash/record.jsf?pid=diva2:325566.

Fanani, M. Z. (2018). Strategi pengembangan soal hots pada kurikulum 2013. Edudeena: Journal of Islamic Religious Education, 2(1). doi: https://doi.org/10.30762/ed.v2i1.582

Ferdig, R., Blank, J., Kratcoski, A., \& Clements, R. (2015). Using stereoscopy to teach complex biological concepts. Advances in physiology education, 39(3), 205-208. doi: 10.1152/advan.00034.2014.

Ibrahim, M. (2016). Pembelajaran Sains di Sekolah Dasar Berbasis Kurikulum 2013. Premiere Educandum: Jurnal Pendidikan Dasar dan Pembelajaran, 4(01). Doi: http:/ / doi.org/10.25273/pe.v4i01.303

Jahne, Bernd. (2002). Digital Image Processing. Tokyo: Springer.

Joseph, Norman. (2011). Stereoscopic Visualization as a Tool for Teaching Astronomy Concepts. (Unpublished master's thesis). Retrieved from https://www.learntechlib.org/p/128483.

Kemendikbud (2018). Buku Pegangan Pembelajaran Berorientasi Pada Keterampilan Berfikir Tingkat Tinggi. Jakarta: DirjenGTK Kemdikbud.

King, F., Goodson, L., \& Rohani, F. (2011). Higher Order Thinking Skills: Definitions, strategies, Assessment. Center for advancement of learning and assessment. Tallahassee: FL : Florida State University. Retrieved from www.cala.fsu.edu

Monnes, Shari. (2013). The Future of 3D Education. Stockholm:Sensavis Education.

Mehrabi, M. G., Peek, E. M., Wuensche, B. C., \& Lutteroth, C. (2013, January). Making 3D Work: A Classification of Visual Depth Cues, 3D Display Technologies and Their Applications. In AUIC (pp. 91-100)

Onural, Levent. (2011). 3D video technologies: an overview of research trends. Washington:SPIE Press.

Peres, Michael. (2007). Focal Encyclopedia of Photography. Oxford:Focal Press. 
Price, C, Aaron., \& Lee, Hee-Sun., D. Plummer, Julia., SubbaRao, Mark \& Wyatt, Ryan. (2015). Position Paper On Use Of Stereoscopy To Support Science Learning: Ten Years Of Research. Journal of Astronomy \& Earth Sciences Education (JAESE). 2 (1), 17-26. doi: 10.19030/jaese.v2i1.9278.

Trindade, J., Fiolhais, C., \& Almeida, L. (2002). Science learning in virtual environments: a descriptive study. British Journal of Educational Technology,33(4), 471-478 https:// doi.org/10.1111/1467-8535.00283

Sara, S., Suhendar, S., \& Pauzi, R. Y. (2020). Analisis Higher Order Thinking Skills (HOTS) Siswa Kelas VIII pada Materi Sistem Pernapasan Manusia. Bioedusiana: Jurnal Pendidikan Biologi, 5(1), 52-61. https://doi.org/10.34289/bioed.v5i1.1654

Shidiq, A. S., Masykuri, M., \& VH, E. S. (2015). Analisis higher order thinking skills (HOTS) menggunakan instrumen two-tier multiple choice pada materi kelarutan dan hasil kali kelarutan untuk siswa kelas XI SMA N 1 Surakarta. In Seminar Nasional Pendidikan Sains V 2015. Sebelas Maret University.

Slameto. (2013). Belajar dan Faktor-Faktor yang Mempengaruhinya. Jakarta: Rineka Cipta.

Zamroni, 2011, Pendidikan Demokrasi pada Masyarakat Multikultural,. Yogyakarta: Gavin Kalam Utama 